\title{
Short Term Vocational Skill Test in Nepalese Context
}

\author{
Rajan Binayek Pasa \\ $\mathrm{PhD}$ scholar Tribhuvan University, Faculty of Education \\ Email for correspondence: rbpshrestha_1942@yahoo.com
}

\begin{abstract}
This paper assesses the possible contribution of short term vocational skill tested graduates and labour migration in foreign employment and remittances to Nepalese economy. An attempt has also been made to assess the role of effective skill testing system that can be provided even in local level as for equal accessibility to all skilled workforces throughout the country. Producing skill tested graduates is known to be a process of human capital formation that is equally benefitted to self and society. Due to easy access of government policy, Nepalese youths are working in international labour market and at a time when the country's major economic indicators are not favorable, the remittances have played a vital role in national economic growth. Though remittances earning is a boon to the economy, the facilities are inadequate to back up the increasing trend of migration. Inadequate knowledge on skill testing system and lack of skill training and poor opportunities to involve in trade specific work are some of bottlenecks to Nepalese youths. This paper suggests that formulation and effective implementation of short term vocational skill testing system in local level is the need of today so that most of foreign labour migrants can grab semi-skilled employment opportunities through specific vocational skill tested certification. . The government needs to play a proactive role to promote foreign employment by inducting and adhering to the policy of socioeconomic development and human capital formation. Replicating the status and impact of short term vocational skill tested graduates and migrated labour in foreign employment, state mechanism has to be endorsed in our national context for development and promotion of skill testing mechanism in local level and regularization of foreign employment. In such a situation, majority of youths could get opportunities to take skill tested certificate that can encourage them to become a vocational skill and trade occupation specific. Such types of work specification could ultimately increase working efficiency and productivity of each workforce and economic prosperity of the country.
\end{abstract}

Key words: Vocational skill test, human capital, remittance

\section{Conceptual Meaning}

Human capital is major foundation for socioeconomic development of the nation even though thousands of youths in the world are seeking jobs without appropriate skills and knowledge (Gilpin, 1999 , p. 68). In this regard, what is needed in the future is preparation of a world-class skilled workforce through vocational training and skill test 
to make industries and firms competitive. Broadly, the purpose of vocational training is three fold; (I) To impart knowledge of production methods, underlying principles and extension of this knowledge to other fields, (II) to get acquainted with works organization and industrial practices and, (III) to understand the sociological aspects of the works community (Mainkar, 2004).

Nepal has a formal body to regulate Technical and Vocational Training in which council for technical education and vocational training (CTEVT) is policy formulation and coordinating body in central level that was established in 1989. It coordinates programs, develops and expands TEVT and ensures quality. It was initially established under the Act, 1989 and amended in 1993.

Talking about organization structures, CTEVT has nine divisions: vocational training and community development division, curriculum development division, skill testing division, research and information division, examination division, planning and policy formulation division, polytechnic division, accreditation division, technical division and administrative division (CTEVT, 2012). Basically, skill testing and accreditation division take responsibility to conduct skill test examination in central level. Apart from skill testing division, there is also an accessibility of skill test in eleven zonal level technical schools in the country. A skill test is the test based performance on defined occupational skill standard that should be performed by every individual to obtain national skill certificate who meets the requirement of a trade or occupation (NSTB, 2012).

It is the skill test system from where students learn about their strengths and weaknesses by the results of tests (Stones, 1979). To provide quality of skill test, it must be psychologically, educationally, psychometrically and instructionally sound because it is said that direct measurement of a person's ability is not possible (Horne, 1984). In this consideration, skill testing system is a one of the vital component of vocational education and training that tries to keep abreast with the labor market trends and providing opportunities to many youths having skills. Each person has a number of 'vocations', of 'careers', of 'callings', as member of a family, having friends and companions (Dewey, 1966).

In this regard, occupational, trade and short term vocational skill testing systems are basically designed to those skilled people who are being acquiring some kind of skills either from formal, non-formal or informal learning process. Therefore, such kind of skill test exam can be opened to all skilled workers and crafts persons in local to central level. The skill training is an unending process for Nepal Labor Force Survey 2008 has depicted that 46.67 percent of population aged 15 and over (14.4 million) has never attended school but they have a certain types of hidden vocational skills (CBS, 2009). In this situation, principally, skill testing system in Nepal has been given higher emphasize to three different target groups; (i) pass outs students of vocational education and skill development training from preemployment vocational training who are being wishing to facilitate their transition to work, (ii) experienced workers: both employed or unemployed who are lacking with an official certification and, (iii) workers who are working at the end of in-service training and seek an upgraded or additional national level certificate (NSTB,2012).

Unfortunately, Nepalese youth and adolescents are still facing various problems, which include lack of awareness/knowledge on skill testing system and poor accessibility and networking of skill testing system in local level. These problems are often worsening by social problems such as inefficient untrained work force, poor skills for employability, unemployment and lower economic growth of the society as well as nation. Many of these problems not only affects the physical and mental health but equally affect youth' long-term emotional, economic and social well-being. For addressing such vulnerable situation, it is essential to improve technical skills and working efficiency of the youths through 
vocational skill testing so that the world will reach its expected goals in future.

Government of Nepal and the World Bank has been implementing enhanced vocational education and skill development training (EVENT) project with the aim of expanding the supply of skilled and employable labor by increasing access to quality training programs, and by strengthening the technical and vocational education and training system in Nepal (MOE, 2013). The project implementation period extends from July 2011 to October 2015. The project has given excessive emphasize on increasing accessibility of technical education and vocational training programs to underprivileged groups like; marginalized Janjati, female and Dalit groups who are being living in the remote rural areas and disabled youths throughout the country. By providing enrollment opportunities to targeted youths, the project has aimed to provide only short term vocational education, skill testing and arrange suitable job placement in national/international labor market (MOE, 2013). Here is why, the primary concern of this paper is to unpack current status and impact of short term vocational skill tested graduates and foreign employment opportunities that can provide opportunities like employability skills and overall productivity to youth and foster human capital formation.

\section{Theoretical Orientation}

According to human capital formation theory, producing skill tested graduates is a process of human capital formation which provides an empirical framework that measures economic relationships (Lekhi, 2008). By applying ideas of human capital theory, educators and education policymakers can formulate their own evaluations of human capital studies from diverse disciplines. Therefore, educators and education policy makers has been establishing the socio-economic relationship among various subject of studies like; sociology, psychology, political science, human resource management, economics and business studies etc. to address public concerns (Schultz, 1961).The human capital theory also can be analyzed from human capability approach that has intrinsic value for the well-being of people by developing personal capacity and getting a real opportunity (Sen, 2000). Reasoning this an individual can foster own knowledge and skill through vocational training and skill testing system so that he or she can get an opportunity to engage in national and international labour market.

Human capital theory thus, treats, schooling as a 'black box', a technical relationship between inputs and outputs. The idea revealed that fixed technical relationships 'between inputs and outputs, as expressed in the form of a production function. Thereby, such schooling system like, school education, higher education and vocational education are based on dominant power relationship and ideology which is deeply rooted in socio-cultural structures (Fine et al., 2001). It is due to this fact, still in Nepalese context most of the youths are working in labour market without vocational training and skill test. However, human capital theory assumes that the labor market is a perfectly competitive one with almost no interaction between these other labor market variables. Thus, the impact of human capital on wages and growth assumes that the economy is at full employment and perfectly competitive.

Early ability (whether acquired or innate), qualifications- knowledge acquired through in/formal and non-formal education and skills, competencies and expertise acquired through training on the job experiences are basic components for human capital formation. According to Schultz (1961), human capital formation can be fostered by providing health facilities to extend life expectancy, on the job training, targeted adult program and assisting their migration in new destinations during their working life (Lekhi, 2008). More so, human capital constitutes the ultimate basis of wealth of nation, accumulates capital, exploit natural resources, builds social, economic and political organization and carry forward national development (Psacharopoulos \& Woodhall, 1987, p.102). In this consideration, state mechanism must realize that human capital formation is a process of investing in human capital if short term vocational 
skill testing opportunities can be provide to local youths for their skill specification and certification (Abeysinghe, 2012).

\section{Policy Perspectives}

Vocational skill has been a highly prioritized area in policy dialogue. After the democratic movement of 1950, importance of technical education and vocational training was realized vocational education and training programs have been launching in different names some times as basic education, sometime as multipurpose schools, sometimes as vocational schools and sometimes as trade schools (Sharma, 2003). More precisely, tenth plan aimed to supply basic and mid-level skilled, technical human resources required by the country (NPC, 2003, p.452). The following are some of the important points mentioned in the Tenth Plan addressing the skills development needs of the poor and disadvantaged; (i) increasing employment opportunities, (ii) promoting access of the poor and disadvantaged to employment, (iii) ensuring the rights of laborers and, (iv) raising quality and productivity. Similarly, Thirteenth three year plan (2013/14-2015/16) aimed to manage human resource development through given objectives; (i) to produce skilled work force who can compete in national and international labor market and maintaining a balance between demand and supply of labor, (ii) to provide qualitative TEVT education and link with employment opportunities and (iii) to interlink all kind of education in to quality, livelihood, skill full, and employability oriented and contemporary (NPC, 2014).

\section{Contextualization}

Nepal has its long history of vocational education though in present context, basic educational system of the country is not vocational in character (Gyani, 1997). In Hindu caste system (after Verna System), vocational work like metal works, leather crafts, and tailoring were considered the work of low caste people. It was due to transformation of traditional cultural understanding on vocational skills, even member from upper and medium caste groups are being applying such types of vocational skills as for their livelihood. Woodcraft and metal crafts reflected in the civilization of Kathmandu Valley shows that vocational education in Nepal is centuries old, but vocational programs followed Gandhian philosophy "Adhar Shikshya" in 1940-50. However, in Lichhavi era, production and enterprise of handicraft, sculpture and architecture by using the skill was learning by the member of many ethnic groups informally prevailed in the Nepalese culture. Afterwards, skilloriented activities and functions were also revealed from the architecture of the Malla era which can be seen in the Kathmandu Valley that the skill-oriented functions were further extended in Malla era (Bista, 1991).

After abolition of Rana regime or the restoration of democracy in 1950, modern education system in Nepal has flourished in a significant way. But modern educational system has been overemphasizing on the theoretical education system to produce unskilled youths. Nepalese youths are being compelled to live either unemployed or underemployed due to lack of vocational training and skill testing opportunities for employability skills. The effects of vocational training and skill test on youth subsequent earnings and career progress in labor market during employability (Greenhalgh \& Mavrotas, 1994). Therefore, basically there are three perspectives for effectiveness of skill test in Nepalese context. (I) Government's perspective: (i) skill test provides opportunity to protect public health and safety by making certification in some occupational areas, (ii) it helps to raise public living standards by influencing the quality and quantity of persons trained in the technical training institutions. (II) Employers' perspective: (i) skill test system makes recruitment of technical staff easier, (ii) it can make easy assessment to make promotions and salary negotiations and (iii) it can help to produce more skillful and competent national level technical workforce. (III) Employees' perspective: (i) skill test helps to achieve proof in his/her specific trade skill, (ii) it provide freedom to employee for moving more 
freely in response to career opportunities in labor market, (iii) it increases opportunities to join labor organizations and (iv) it made training programs more efficient and effective and also increases pride and status of the institutions (NSTB, 2012).

For providing skill testing opportunities to Nepalese youths, skill testing division has been taking responsibility of certifying the skill level of individuals to know whether they have been trained appropriately or not. The division has been conducting examinations to all basic, mid and higher level manpower throughout the country and national skill competitions in various occupational areas. They also provide skill test opportunities to those who have acquired vocational related skills informally. Similarly, the division develops the dictionary of occupational classification suitable to Nepalese context and also provides an opportunity for enhancing career of the industry workers and individuals (CTEVT, 1994, p.14). Table No. 1: Requirements to Participate in Short term Skill Test

\begin{tabular}{ll}
\hline Test Level & Requirements \\
\hline LEVEL 1 & -Literate with knowledge \& \\
& skill in the relevant \\
& occupation with minimum of \\
& one year work experience in \\
& a related occupation/trade. \\
& -Successful completion of \\
& one month (160 hours) \\
& vocational training in relevant \\
& occupation/trade. \\
& -Vocational training with six \\
& months work experience in \\
& the relevant occupation/trade \\
\hline
\end{tabular}

(NSTB, 2012)

Currently, in addition to the government, there are more than eleven donors that are supporting to enroll about 40000 youths in their vocational skill training every year (CTEVT, 2011). In this context the role of short term vocational skill test becomes a crucial instrument to impart various trade related skills for finding gainful employment to those school drops out youths. Approximately, 25000 persons obtaining technical education and more than 50000 youths participated in vocational training every year through government and non-government agencies (TEVT, 2012).

Table No. 2: Number of Short Term Skill Tested Graduates in 2012

\begin{tabular}{lll}
\hline $\begin{array}{l}\text { Development Region } \\
\text { (DR) }\end{array}$ & Frequency & Percentage \\
\hline Eastern DR & 10065 & 18.19 \\
\hline Central DR & 19651 & 35.52 \\
\hline Western DR & 12174 & 22.01 \\
Middle Western DR & 6899 & 12.47 \\
Far Western DR & 6522 & 11.79 \\
Total & $\mathbf{5 5 3 1 1}$ & $\mathbf{1 0 0}$ \\
\hline (CTEVT, 2012) & &
\end{tabular}

The information on table 2 shows the number of short term vocational skill tested graduates throughout the country. Most (35.52\%) of the skill tested graduates are from central development region and least $(11.79 \%)$ from far-western development region. Similarly, out of total skill tested graduates, 22.01 percent are from western development region, 18.19 percent are from eastern development region and remaining 12.47 percent are from middle-western development region. But my concern is that how numbers of short term vocational skill tested graduates can be increased in Middle Western and Far Western Development Region? May be it is necessary to communicate about short term vocational skill testing system in these regions and local youths have to become curious to participate in interested short term vocational skill training programs as well. The working age population (aged 15 to 59 years) has increased from 54 percent $(12,310,968)$ in 2001 to about 57 Percent $(15,091,848)$ in 2011 showing the population structure is shifting for enjoying demographic dividend in the country. It is the reason behind why labor migration for overseas employment has rapidly increased particularly after globalization though short term skill tested graduates are comparatively minimal as compared to 55311 short 
term skill tested graduates in 2012 and 15,091,848 working age population in same year. However, the Nepalese economy is increasingly becoming dependent on remittance sent home by migrant workers. The numbers of remittance receiving households are increasing yearly in Nepal (CBS, 2011). The report highlights that it was $23.4 \%$ and $31.9 \%$ in the years $1995 / 96$ and $2003 / 04$ followed by a sharp increase in 2010/11 at 55.8\%. Nepal received NRs. 259 billion remittance in the year 2010/11 that was recorded only NRs. 13 billion and NRs. 46 billion in the respective years 1995/99 and $2003 / 04$. In terms of per-capita remittance too, the data reveals a remarkable increase during these decades that stood only NRs. 625 and NRs. 2100 in the years 1995/96 and 2003/04 and jumped to NRs. 9245 in 2010/11 (MOF, 2011).

This fact indicates that Nepalese youths are getting employment opportunities in international labour market. One in every four households $(25.42 \% ; 1.38$ million households) reported that at least one member of their household is absent or is living out of country. Total number of absent population is found to be $1,921,494$ in 2011 against 762,181 in 2001. A total of 2,226,152 labour permits were issued over the six-year period, representing a staggering 137 per cent increase between 2008/09 and 20013/14, which represents about 8 per cent of Nepal's total population. But most of the overseas migrated youth $(70 \%$ of youth of 354000 those migrated in FY 2067/2068) neither took any skill development training nor participated in short term vocational skill test and compelled to work danger, difficult and dirty jobs (CTEVT, 2011).

Vocational knowledge and skill test is therefore considered occupation specific (Beck, Kabst $\&$ Walgenbach, 2009). Skill Testing is needed to ensure the level of skills by the Nepali when they go abroad but from the 187 sample vocational graduate youth, more than $80 \%$ did not hear about the National Skill Test. It is important to note that many are interested in the test among those who never heard of it (Kusago \& Phuyal, 2009). The widespread confidence in the ability of laborers to acquire skills without undue difficulty was based, in part at least, upon the assumption that a satisfactory standard of elementary training and their active participation in skill test examination before entering into labor market (Hollander, 1968).

Table No. 3: Number of Labour Migrants in 2013/14

\begin{tabular}{lll}
\hline $\begin{array}{l}\text { Development Region } \\
\text { (DR) }\end{array}$ & Frequency & Percentage \\
\hline Eastern DR & 134656 & 29.95 \\
\hline Central DR & 154763 & 34.43 \\
\hline Western DR & 91810 & 20.42 \\
\hline Middle Western DR & 48917 & 10.88 \\
\hline Far Western DR & 19337 & 4.30 \\
\hline Total & $\mathbf{4 , 4 9 , 4 8 3}$ & $\mathbf{1 0 0}$ \\
\hline
\end{tabular}

(Department of Foreign Employment)

The information on table 3 shows the number of youth migrated in foreign employment throughout the country. Most (34.43\%) youths are migrated from central development region and least (4.30\%) from far-western development region. Similarly, out of total migrated labours 29.95 percent are from central development region, 20.42 percent are from western development region and remaining 10.88 percent are from middle-western development region. If we compare short term skill tested graduates (2012) with total migrated foreign labour (2013/14) we find very few skill tested youths are working in international labour market. Annually only a few more than 50000 youths are participating in short term vocational skill test whereas more than 4, 49,483 youths are migrating for foreign employment. Therefore, it is essential to foster the accessibility and networking of short term vocational skill test in local level so that Nepalese skilled youths can easily participate in skill testing system and make their working life productive and effective even in national and international labour market.

\section{Conclusion}

Short term vocational skill testing system is a process of producing skilled work force or human capital. The system is more relevant in Nepalese context where most of the youths have poor access of 
vocational education and training but have certain types of vocational based skills. Nepal Labor Force Survey 2008 has also depicted that 46.67 percent of population aged 15 and over (14.4 million) has never attended school but they have certain types of hidden vocational skills (CBS, 2009).

Skill testing and accreditation division under CTEVT and eleven zonal level technical schools are taking responsibility to conduct skill test examination in the country. Skill test is regarded as test based performance on defined occupational skill standard that must be performed by every individual to obtain national skill certificate who meets the requirement of a trade or occupation (NSTB, 2012). Principally, skill testing system in Nepal has been given higher emphasize to pass out students of vocational education and skill development training, experienced workers both employed or unemployed who are lacking with an official certification and workers who are working at the end of in-service training (NSTB, 2012).

EVENT project has also given excessive emphasis on increasing accessibility of technical education and vocational training programs to underprivileged groups by providing opportunities in short term vocational education and skill testing and arrange suitable job placement in national/international labor market (MOE, 2013). However Nepalese Government has been implementing various policies, plan and projects to increase accessibility of youths in vocational training and skill testing system but still annually only 50000 youths participated in short term vocational skill test where more than 400000 youths migrated for foreign employment.

Theoretically producing skill tested graduates is the process of human capital formation that is ultimate basis for overall development of the country. Vocational skill has been a key component for livelihood in Nepalese historical and cultural context which is equally significant from government, employers and employee perspectives but still majority of the youths are working in international labour market without any skill tested certification though Nepalese economy is remittance based economy and where per-capita remittance of NRs. 2100 in 2003/04 jumped to NRs. 9245 in 2010/11 (MOF, 2011). Therefore it is inevitable to provide short term vocational skill testing opportunities to all youths in local level so that they can get skill tested certificate and become specific in certain trade occupation. It will definitely increase their occupational knowledge, working efficiency and economic productivity in national/international labour market.

\section{References}

Abeysinghe, A. M. G. B. (2012). Human capital formation: Trends and problems Tuesday 10 January 2012 09; 49. Corporate Management Division, University of Peradeniya, Srilanka.

Beck, N., Kabst, R. \& Walgenbach, P. (2009): The cultural dependence of vocational training. Journal of International Business Studies, 40(8), 1374- 1395. Retrieved from http://www.jstor.org/ stable/27752452

Bista, D. B. (1991). Fatalism and development: Nepal's struggle for modernization. Kathmandu: Sangam Books Limited.

Central Bureau of Statistics (CBS, 2011). Populationcensus report 2012. Kathmandu: Author.

CBS (2009). Preliminary findings of NLSS-III. Kathmandu: Author. ( Retrieved from:www.cbs.)

Council for Technical Education and Vocational Training (CTEVT). A report on national skill test board, 2012.Bhaktapur: Author.

CTEVT (1994). CTEVT Profile, Kathmandu: Author.

CTEVT (2005). Report of research and information division. Bhaktapur: Nepal.

CTEVT (2011). A study on the trends analysis of foreign employment and skill gap, July 2011. Unpublished. 
CTEVT. (2012). Technical and Vocational Education and Training Policy, 2012.Sanothimi, Bhaktapur: Author

Department of Foreign Employment (2011). The report of number of approved migrated workers from FY 2063 to 2067/68.

Dewey, J. (1966). Democracy and Education (pp. 306-320). London: Macmillan, Free Press Paperback Edition,

Fine, B, Lapavitsas, C, \& Pincus, J (Eds) (2001): Development policy in the twenty-first century. Beyond the post-Washington consensus. London: Routledge.

Gilpin, W. (1999). Workforce education: The nexus between capitalism and democracy. Journal of Industrial Teacher Education, 33(4), 66-69.

Greenhalgh, C. \& Mavrotas, G. (1994). The role of career aspirations and financial constraints in individual access to vocational training. Oxford Economic Papers, New Series, 46(4), 579-604. Retrieved from http://www.jstor.org/stable/ 2663512 .

Gyani, S. D. (1997). Vedakal in Samaj [Vedic Society].Varanasi: Chowkhamba Vidyabhawan.

Hollander, S. (1968). The role of the state in vocational training: the classical economists' view. Southern Economic Journal, 34(4), 513 525. Retrieved from http://www.jstor.org/stable/ 1056929

Horne, S. (1984). Criterion-referenced testing: pedagogical implications. British Educational Research Journal, 10 (2), 155-173. Retrieved from http://www.jstor.org/stable/1500751

Kusago, T. \& Phuyal, K. (2009).TVET and Secondary School Education in Nepal: A case study of Hetauda, Makwanpur. Purbanchal University, Nepal.
Lekhi, R. K. (2008). The economics of development and planning (11th ed.). New Delhi: Kalyani Publishers.

Mainkar, S.V. (2004). Vocational training of chemical engineers in Poland. Raipur, India: Department of chemical engineering, government collage of engineering and technology, Government of India.

Ministry of Education (MOE) (2013). Enhanced Vocational Education and Training Project (EVENT) (2011-2015). Terms of Reference for Delivering Vocational Training and Employment Services for Targeted Youths under Results-based Short-term Training.

Ministry of Finance (2011). Economic Survey Fiscal Year 2010/2011 Vol. Kathmandu, Nepal: Author.

National Planning Commission (2003). Tenth five year plan. Author.

National Planning Commission (2013).Thirteenth three year plan (2013/14-2015/16.

Psacharopulos, G \& Woodhall, M. (1997). Education for developemtn: An analysis of investment choice. New York: Oxford University Press.

Schultz, T. W. (1961). Investment in human capital [Presidential address delivered at the annual meeting of the American Economic Association, Saint Louis, MO, December, 1960]. The American Economic Review, 51, 1-17.

Sen, A. (2000). Commodities and Capabilities: Development as Freedom. Oxford University Press.

Sharma, T.N. (2003). Possibilities and challenges of Vocational Education. Journal on Distance Education, (1), 15-26.

Stones, E. (1979).Psychopedagogy. London: Methuen. 